Sharif University of Technology
Scientia Iranica
Transactions C: Chemistry and Chemical Engineering
w
I RANw.scientiairanica.com

\title{
Petroleum refinery wastewater treatment in two-chamber Microbial Fuel Cells (MFCs)
}

\author{
M. Bagheri-Esfe ${ }^{*, a}$ and H. Bagheri-Esfe ${ }^{b}$ \\ a. Department of Chemical Engineering, Isfahan University of Technology, Isfahan, P.O. Box 84156-83111, Iran. \\ b. Faculty of Engineering, University of Shahreza, Shahreza, P.O. Box 86149-56841, Iran. \\ Received 19 May 2015; received in revised form 7 November 2015; accepted 2 May 2016
}

\author{
KEYWORDS \\ Petroleum refinery \\ wastewater; \\ Microbial fuel cell; \\ Chemical oxygen \\ demand.
}

\begin{abstract}
Petroleum Refinery Wastewaters (PRW) contain water-soluble hydrocarbons which cannot be separated by physical methods. In recent years, there have been enormous approaches to treat PRW. The most outstanding methods involve biological, photocatalytic, electro- and photo-Fenton, etc. Using microbial fuel cell is a new method to treat PRW. In this paper, PRW treatment in MFC was studied using oxygen and permanganate as cathodic electron acceptors. Also, effects of temperature and external resistance on MFC performance and PRW treatment were investigated. Finally, an electrochemical model was fitted on empirical polarization curves to evaluate activation, ohmic, and mass transfer losses. Maximum power production was $0.03 \mathrm{~W} / \mathrm{m}^{2}$ at $33^{\circ} \mathrm{C}$ using oxygen as cathodic electron acceptor. Also, COD removal efficiency was $49.27 \%$ during $44 \mathrm{~h}$. To enhance power production of the MFC, potassium permanganate was used as cathodic electron acceptor. At the temperature of $33^{\circ} \mathrm{C}$ and $0.2 \mathrm{~g} / \mathrm{L}$ of permanganate concentration, the maximum power density was $0.95 \mathrm{~W} / \mathrm{m}^{2}$ and COD removal efficiency was $78 \%$ during $44 \mathrm{~h}$.

(C) 2016 Sharif University of Technology. All rights reserved.
\end{abstract}

\section{Introduction}

Refining process generates wastewater (0.4-1.6 times the volume of the crude oil processed) [1]. Petroleum Refinery Wastewater (PRW) contains water-soluble hydrocarbons including phenol, benzene, xylenes, and other pollutants that are carcinogenic [2]. In the recent years, many efforts have been done for treating PRW. PRW has two aqueous and oily phases. Oily phase is separated by physical methods. The main output of the physical process is aqueous phase that contains suspended oil and also solid particles. Then, during the second treatment stage, the suspended particles are separated by coagulation. The output of this stage is a homogenous aqueous phase containing water dissolved

*. Corresponding author. Tel./Fax: +98 3133912862 E-mail address: mehdibagheri5671@gmail.com ( $M$. Bagheri-Esfe) hydrocarbons, which cannot be separated by physical methods. Biological approaches are traditional methods to treat this wastewater [3-6]. Biological process utilizes microorganisms to oxidize organic matter to simple products $\left(\mathrm{CO}_{2}, \mathrm{H}_{2} \mathrm{O}\right.$, and $\left.\mathrm{CH}_{4}\right)$ [7].

In the recent years, advanced oxidation methods have been developed for PRW treatment such as photocatalytic and photo-Fenton methods [8-9] that are based on direct oxidation of water dissolved hydrocarbons. All of the mentioned methods, however, require catalyst, large amount of oxidant, and high energy consumption. PRW treatment by microbial fuel cell as an indirect oxidation method can be considered as a cost effective method not only because of low energy demands but also due to its power output to supply energy for treatment unit [10]. Various wastewater treatments including municipal wastewater, dairy wastewater, beer factory wastewater, etc. have been investigated using MFC [11-14]. Previous studies about 
PRW treatment in MFC are restricted to oil phase, which is insoluble in water and can be easily separated by physical methods [15-17].

However, degradation of hydrocarbons soluble in PRW using two-chamber MFC has not been investigated. Certainly, elimination of water dissolved hydrocarbons (such as pure phenol) in microbial fuel cell has been performed [18].

In the present paper, a two-chamber microbial fuel cell was applied to treat Isfahan petroleum refinery wastewater. In the MFC, dissolved petroleum hydrocarbons are degraded by anaerobic microorganisms at the anode chamber. As a result of degradation process, electrons travel through external resistance and protons pass through proton exchange membrane. The corresponding protons migrate to the cathodic chamber. At the cathode, an electron acceptor is reduced by the electrons via the circuit and the protons via the membrane [19]. In this study, oxygen and potassium permanganate were used as cathodic electron acceptors and their relevant results were compared. Then, effects of temperature and external resistance on treatment of PRW were investigated. Finally, an electrochemical model was fitted on empirical polarization curves to evaluate activation, ohmic, and mass transfer losses in the air cathode MFC and MFC with permanganate oxidant.

\section{Materials and methods}

\subsection{Fuel cell configuration}

A dual-chamber fuel cell was used in the present paper. Cathode and anode chambers were constructed cubically using plexiglass with the volume of $350 \mathrm{ml}$. A $30 \mathrm{~cm}^{2}$ proton exchange membrane was embedded between two chambers. Non-catalyzed carbon cloths (E-TEK, USA, $10 \mathrm{~cm}^{2}$ ) were used as electrodes for both cathode and anode. The distance between anode and cathode electrodes was constant in all experiments $(2 \mathrm{~cm})$. Copper wires were used for contact with electrodes after sealing the contact area with 'epoxy' material. A magnetic mixer (100 rpm) was exerted under anode chamber to prevent concentration polarization. In addition, to prevent concentration polarization in the cathode chamber, catholyte was recycled between the cathode chamber and external resource by a peristaltic pump. When oxygen was used as reducing factor, phosphate buffer (100 mM, $\mathrm{pH}=7$ ) along with aeration was used as catholyte. When potassium permanganate was applied as a reducing factor, $0.2 \mathrm{~g} / \mathrm{L}$ of potassium permanganate in phosphate buffer (100 mM, pH $=7$ ) was pumped to the cathode chamber. The automatic voltage recorder was embedded parallel to external resistance in circuit to record voltage. NAPHION 117 was used as proton exchange membrane. Preparation stages were carried out before using the above proton exchange membrane [20]. Water bath containing MFC was fixed at the considered temperature by control system.

\subsection{Inoculation and wastewater characteristics}

Anaerobic activated sludge, containing a significant amount of electrogenic bacteria [21], collected from anaerobic treatment rectors of Isfahan Refinery Company was used as microorganism and enriched for approximately 2 months (start-up period). MFC performance is significantly affected by structure and morphology of the biofilm grown during the start-up period on the anode surface. The biofilm established on the anode surface under relatively low external resistance contains more active biomass than that under high resistance [22]. Thus, external resistance of $500 \Omega$ was selected during the start-up of the MFC. Characterization of the biofilm on the anode surface of a diesel-degrading MFC showed that the majority of the bacteria were facultative $\gamma$-proteobacteria such as Citrobacter sp., Stenotrophomonas sp., and Pseudomonas sp. [16]. Furthermore, diluted PRW obtained from Isfahan Refinery was used as substrate for microorganisms. This substrate, in fact, is a diluted wastewater passing through elementary and secondary pretreatment stages and is a homogenous wastewater with $\mathrm{COD}=213.9 \mathrm{mg} / \mathrm{L}, \mathrm{pH}=7$, and Turbidity $=82$ NTU.

\subsection{Measurement of chemical oxygen demand} Chemical oxygen demand is the main characteristic of any wastewater, evaluated as index of MFC performance. In the present research, APHA standard method was used to measure COD [23].

\subsection{Calculations}

\subsubsection{Current intensity and power}

Current intensity and power are the most important parameters that should be measured. Current intensity was evaluated by using Ohm law:

$$
I=V / R
$$

where $V$ and $R$ denote, respectively, potential difference and external resistance.

In addition, power was obtained using the following equation:

$$
P=I V \text {. }
$$

Power density $\left(\mathrm{W} / \mathrm{m}^{2}\right)$ and current density $\left(\mathrm{A} / \mathrm{m}^{2}\right)$ are calculated by dividing power and current intensity to the anodic surface area $\left(\mathrm{m}^{2}\right)$.

\subsubsection{Columbic efficiency}

Columbic efficiency is defined as the ratio between the charge transported to anode and maximum charge, which might be obtained from total substrate degra- 
dation. This parameter is evaluated as follows [24]:

$$
C_{E}=\frac{8 \int_{0}^{t_{b}} I d t}{F V_{A n} \Delta(\mathrm{COD})},
$$

where $I$ is the electrical current intensity, $F$ the Faraday's constant, $V_{A n}$ the anaerobic chamber volume, and $\Delta(\mathrm{COD})$ the overall removal of substrate during $t_{b}$.

\section{Results}

\subsection{MFC performance using oxygen electron acceptor}

Firstly, temperature of the water bath was fixed at $33^{\circ} \mathrm{C}$ and $50 \mathrm{ml}$ of anaerobic activated sludge and $300 \mathrm{ml}$ of PRW were injected to MFC. Immediately after wastewater injection to anode chamber, voltage reached $44 \mathrm{mV}$ with external resistance of $200 \Omega$. This abrupt rise to the peak voltage is attributed to existence of biofilm grown during the start-up period on the anode surface [22]. Furthermore, response of MFC to wastewater injection at low external resistances is faster than that at high external resistance [25]. Then, voltage began to decrease so that it reached $18 \mathrm{mV}$ after $25 \mathrm{~h}$. This voltage reduction was due to decrease of the substrate concentration available for microorganisms. After that, we turned off magnetic mixer under anode chamber and waited for an hour until suspended sludge settled. The main purpose was to use active microorganism in the next stage. Then, $300 \mathrm{ml}$ of wastewater was replaced with fresh wastewater, which is shown in Figure 1 with the first arrow.

After injection, voltage immediately increased to $55 \mathrm{mV}$. After some hours of halting, it was reduced to $20 \mathrm{mV}$ during $44 \mathrm{~h}$ (Figure 1). Then, the temperature of water bath containing MFC was fixed at $24^{\circ} \mathrm{C}$ and fresh wastewater was replaced again. As MFC was reinjected at ambient temperature $\left(24^{\circ} \mathrm{C}\right)$, voltage immediately increased to $37 \mathrm{mV}$ and after some hours

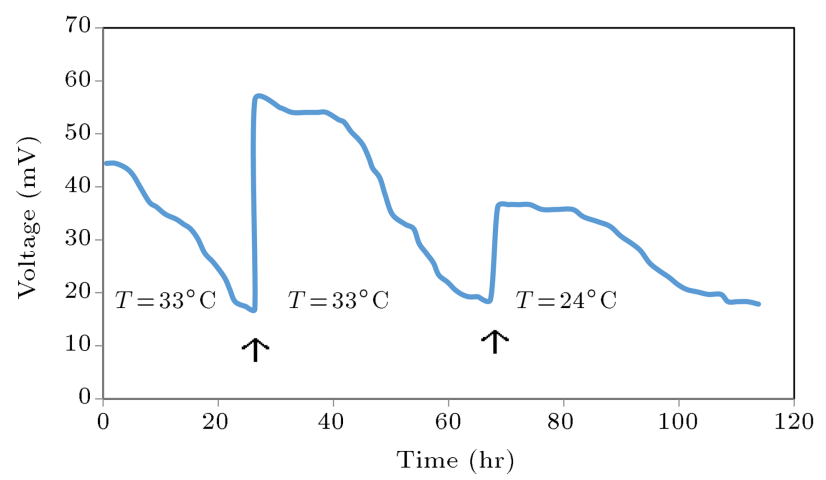

Figure 1. Voltage variations vs. time using oxygen electron acceptor under temperatures of $24^{\circ} \mathrm{C}$ and $33^{\circ} \mathrm{C}$.

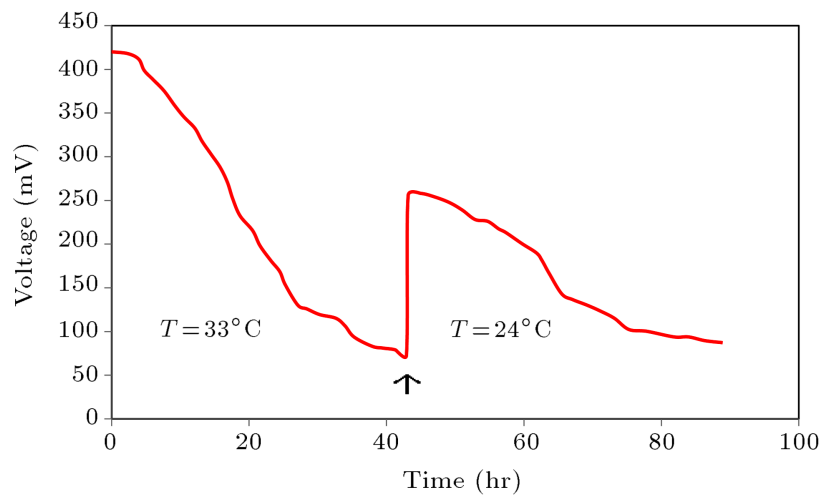

Figure 2. Voltage variations vs. time using potassium permanganate electron acceptor under temperatures of $24^{\circ} \mathrm{C}$ and $33^{\circ} \mathrm{C}$ with $200 \Omega$ of resistance.

of halting, it began to decrease. In fact, reduction of maximum voltage with decreasing temperature is due to reduction in activity of the microorganism and reduction potential of the cathode [26].

\subsection{Using potassium permanganate as cathodic electron acceptor}

The temperature of water bath was fixed at $33^{\circ} \mathrm{C}$. $300 \mathrm{ml}$ of fresh wastewater was added into anode chamber and $0.2 \mathrm{~g} / \mathrm{L}$ of potassium permanganate solution was pumped into the cathode chamber from an external source and vice versa to prevent polarization in the cathode chamber. Initial voltage of MFC was $420 \mathrm{mV}$. After some hours, voltage began to decrease. Figure 2 shows voltage variations versus time under temperatures of $24^{\circ} \mathrm{C}$ and $33^{\circ} \mathrm{C}$.

Comparison between Figures 1 and 2 shows that slope of voltage variations using potassium permanganate as electron acceptor is more than another one. The reason is that higher current is generated using permanganate and much substrate degrades. With regard to Figure 2, it is clear that after $44 \mathrm{~h}$, cell voltage decreased to $72 \mathrm{mV}$. Then, we turned off magnetic mixer under anode chamber and waited for an hour until suspended sludge settled. Then, the temperature of water bath was fixed at $24^{\circ} \mathrm{C}$ and fresh wastewater was added again, which is shown in Figure 2 with arrow. Initial voltage at $24^{\circ} \mathrm{C}$ was $259 \mathrm{mV}$ and it reached $83 \mathrm{mV}$ after $44 \mathrm{~h}$.

\subsection{COD Removal}

COD is amount of required oxygen to convert total organic matter present in wastewater into carbon dioxide and water. Treatment process reduces COD. Figures 3 and 4 show, respectively, COD removal of PRW versus time using oxygen and potassium permanganate as cathodic electron acceptors, with $200 \Omega$ of external resistance at temperatures of $24^{\circ} \mathrm{C}$ and $33^{\circ} \mathrm{C}$.

As can be seen in Figures 3 and 4, COD removal efficiencies were $49.27 \%$ and $78.26 \%$ at $33^{\circ} \mathrm{C}$ during $44 \mathrm{~h}$ in the presence of oxygen and potassium perman- 


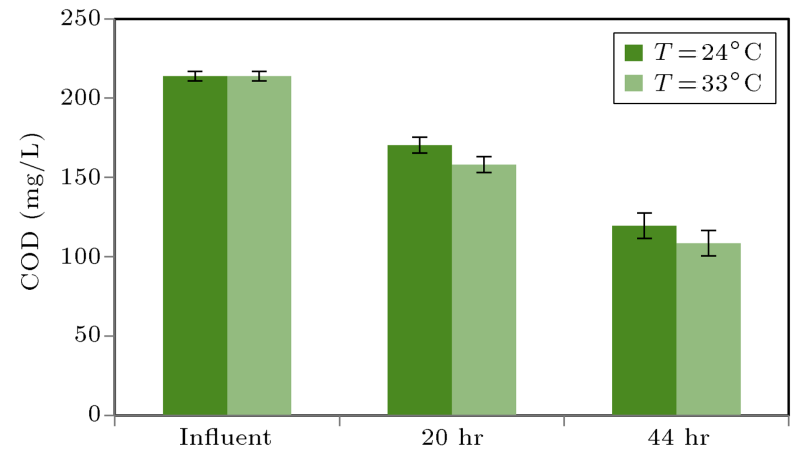

Figure 3. COD removal of PRW vs. time using oxygen as cathodic electron acceptor with $200 \Omega$ of external resistance at temperatures of $24^{\circ} \mathrm{C}$ and $33^{\circ} \mathrm{C}$.

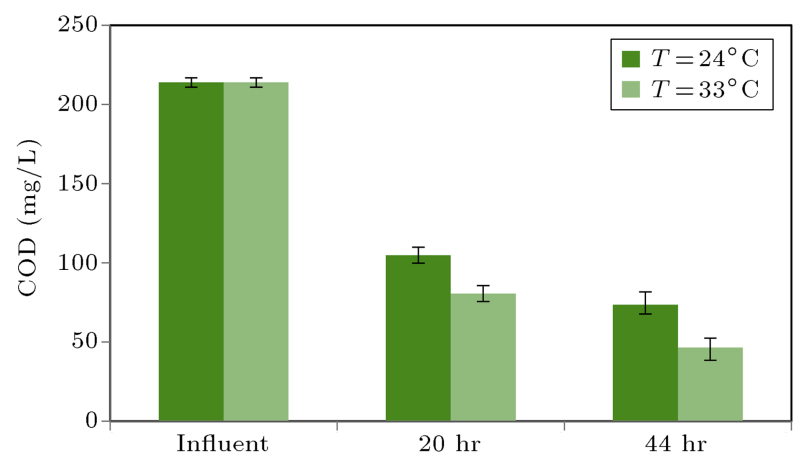

Figure 4. COD removal of PRW vs. time using potassium permanganate with $200 \Omega$ of external resistance at temperatures of $24^{\circ} \mathrm{C}$ and $33^{\circ} \mathrm{C}$.

ganate, respectively. Also, COD removal efficiencies were $44.08 \%$ and $65.54 \%$ at $24^{\circ} \mathrm{C}$ during $44 \mathrm{~h}$ in the presence of oxygen and potassium permanganate, respectively.

\subsection{Columbic efficiency}

Using Eq. (3), the values of Columbic Efficiency $\left(C_{E}\right)$ with $200 \Omega$ of external resistance were $6.05 \%$ and $4.77 \%$ during $44 \mathrm{~h}$ in the presence of oxygen at $33^{\circ} \mathrm{C}$ and $24^{\circ} \mathrm{C}$, respectively. Also, the values of $C_{E}$ were $25.4 \%$ and $20.175 \%$ during $44 \mathrm{~h}$ using potassium permanganate at $33^{\circ} \mathrm{C}$ and $24^{\circ} \mathrm{C}$, respectively. Thus, it is obvious that using permanganate as electron acceptor has more advantages than oxygen, such as higher values of removal COD and $C_{E}$. As pointed earlier, the reason is that the rate of oxidation of wastewater by microorganisms is higher due to effective $e^{-}$discharge and higher current generation using permanganate as electron acceptor [27].

\subsection{Effect of external resistance variation on treatment of PRW}

To investigate effect of external resistance variation on PRW degradation, the MFC with $3000 \Omega$ of resistance was started up in the presence of oxygen and permanganate, separately, by injection of fresh wastewater. Maximum generated currents during $44 \mathrm{~h}$

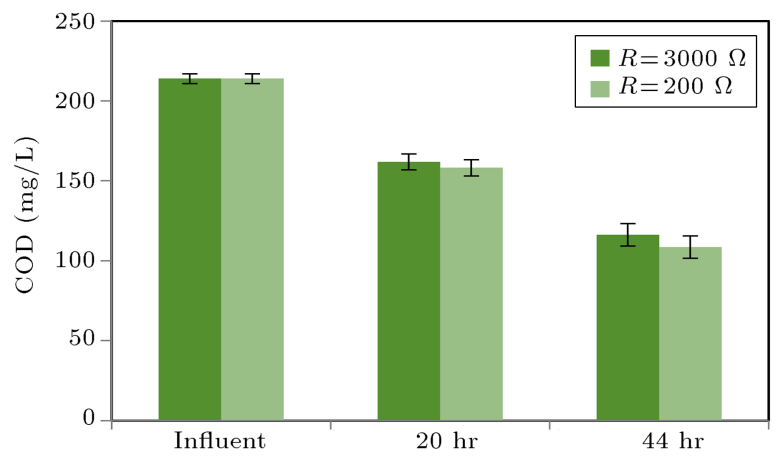

Figure 5. COD variations of PRW using oxygen as electron acceptor at temperature of $33^{\circ} \mathrm{C}$ with $3000 \Omega$ and $200 \Omega$ of resistance during $44 \mathrm{~h}$.

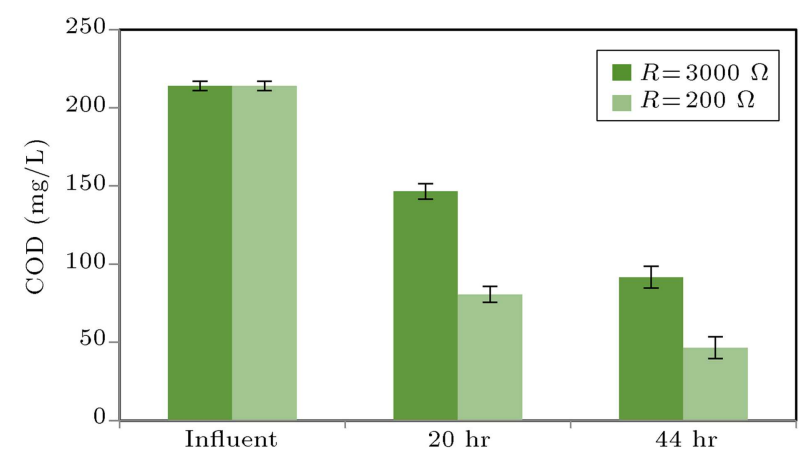

Figure 6. COD variations of PRW using permanganate as electron acceptor at temperature of $33^{\circ} \mathrm{C}$ with $3000 \Omega$ and $200 \Omega$ of resistance during $44 \mathrm{~h}$.

were equal to $0.09 \mathrm{~A} / \mathrm{m}^{2}$ and $0.36 \mathrm{~A} / \mathrm{m}^{2}$ for oxygen and permanganate electron acceptors, respectively, which were 3.2 and 5.8 times less than those with $200 \Omega$ of resistance.

Figures 5 and 6 show COD variations of PRW at the temperature of $33^{\circ} \mathrm{C}$ with $3000 \Omega$ in comparison with $200 \Omega$ of resistance using oxygen and permanganate electron acceptors, respectively.

As shown in Figure 5, COD removal efficiencies are almost equal for two resistances, although maximum generated current with $3000 \Omega$ is 3.22 times higher than another, because columbic efficiency is low using oxygen as electron acceptor. In fact, the MFC has negligible effect on treatment of PRW.

Figure 6 shows that COD removal efficiencies are equal to $57.12 \%$ and $78.26 \%$ after $44 \mathrm{~h}$ for $3000 \Omega$ and $200 \Omega$, respectively. The difference between these two values is high in contrast to that in aerated cathode MFC, because when permanganate is used as electron acceptor, the value of $C_{E}$ is higher.

\subsection{Polarization behavior}

To plot polarization and power density curves, it is necessary to calculate output current intensity and power density (using Eqs. (1) and (2)) over a range of 50-5000 $\Omega$ for the external resistance. Polarization and power density curves of aerated cathode MFC at the 


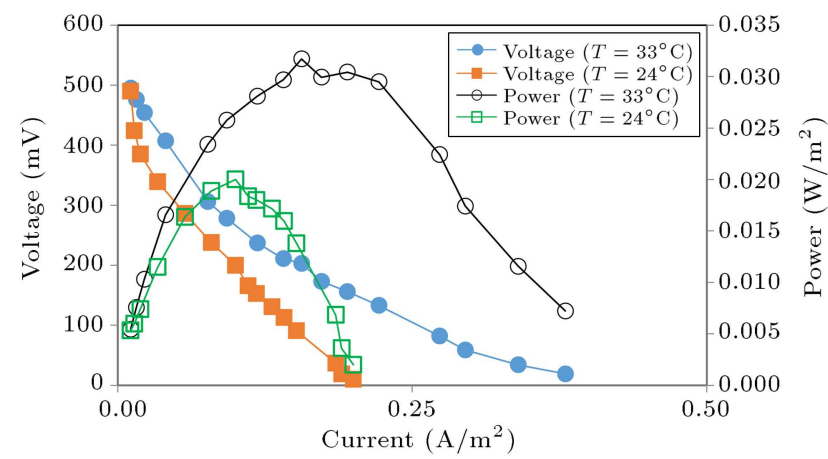

Figure 7. Polarization and power density curves of aerated cathode MFC at the temperatures of $24^{\circ} \mathrm{C}$ and $33^{\circ} \mathrm{C}$.

temperatures of $24^{\circ} \mathrm{C}$ and $33^{\circ} \mathrm{C}$ have been illustrated in Figure 7.

As shown in Figure 7, when external resistance decreases, the MFC voltage is reduced and current density increases. MFC internal resistance (that is determined by maximum point of power density curve where external resistance is equal to internal resistance [25]) is equal to $1300 \Omega$ and $2000 \Omega$ at $33^{\circ} \mathrm{C}$ and $24^{\circ} \mathrm{C}$, respectively. Also, maximum power densities at $33^{\circ} \mathrm{C}$ and $24^{\circ} \mathrm{C}$ are $0.03 \mathrm{~W} / \mathrm{m}^{2}$ and $0.02 \mathrm{~W} / \mathrm{m}^{2}$, respectively. Thus, it can be concluded that temperature reduction increases cell internal resistance and decreases power output. Internal resistance of the $\mathrm{MFC}$ is a result of activation losses due to reaction kinetics that take place on the cathode and the anode, ohmic losses due to ionic and electronic resistances, and concentration losses due to mass transport limitations [28].

Since power generation using aerated cathode MFC was low, potassium permanganate as effective cathodic electron acceptor was used. Permanganate redox potential is a function of its concentration in cathode chamber and $\mathrm{pH}$. By using Nernst equation and theoretical potential $\left(E^{0}\right)$ of $1.51 \mathrm{~V}$ at $33^{\circ} \mathrm{C}$, potential of cathode can be described as follows [29]:

$$
\begin{aligned}
& E_{\text {cathode }}=1.51+0.0052 \log \left[\mathrm{Mno}_{4}^{-}\right]-0.0422 \mathrm{pH}, \\
& \mathrm{Mno}_{4}^{-}+8 \mathrm{H}_{3} \mathrm{O}^{+}+5 e^{-} \rightarrow \mathrm{Mn}^{2+}+12 \mathrm{H}_{2} \mathrm{O}
\end{aligned}
$$

The values of cathode potential for permanganate concentrations of $0.05,0.1,0.2$, and $0.3 \mathrm{~g} / \mathrm{L}(3.16 \times$ $10^{-4}, \quad 6.33 \times 10^{-4}, 12.66 \times 10^{-4}$, and $19 \times 10^{-4}$ $\mathrm{mol} / \mathrm{L}$ ) are $1.196,1.198,1.199$, and $1.2 \mathrm{~V}$, respectively, for $\mathrm{pH}=7$ and $T=33^{\circ} \mathrm{C}$. It indicates that the value of theoretical redox potential is insensitive to permanganate concentration.

In practice, increasing the permanganate concentration increases the electrolyte conductivity and decreases ohmic and activation losses that increase power of MFC. Also, manganese dioxide is the main product of redox reaction and its sediment on cathode limits electron transfer and MFC performance. This

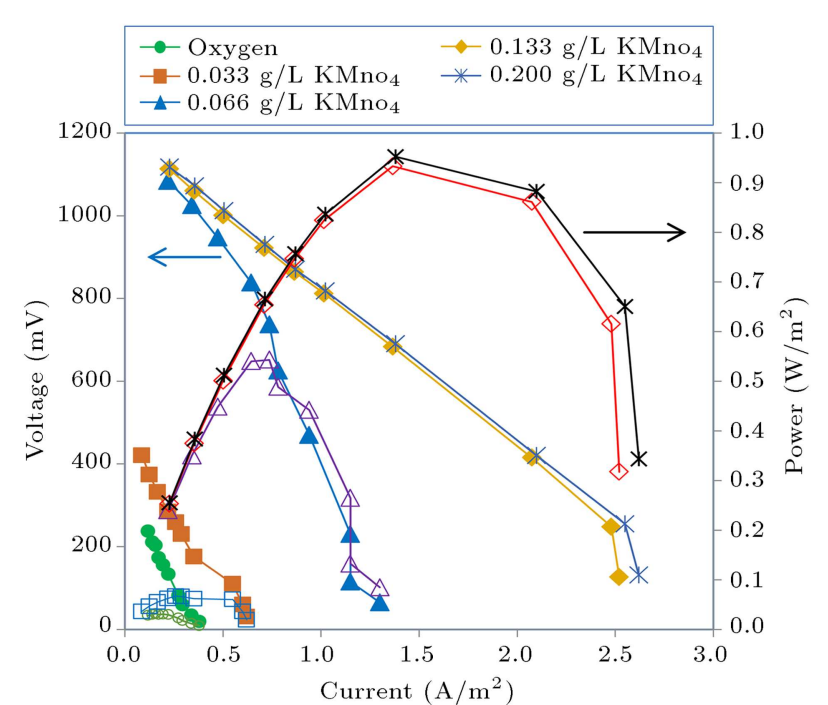

Figure 8. Polarization and power density curves at $33^{\circ} \mathrm{C}$ using potassium permanganate in different concentrations in comparison to aerated cathode MFC.

means that MFC should be operated at relatively low permanganate concentration [29].

Figure 8 shows polarization and power density curves at concentrations of $0.033,0.066,0.133$, and $0.2 \mathrm{~g} / \mathrm{L}$ for potassium permanganate and the results are compared with aerated cathode $\mathrm{MFC}$ data (at $33^{\circ} \mathrm{C}$ ). As can be seen in Figure 8 , at $0.2 \mathrm{~g} / \mathrm{L}$, the value of power variation is negligible that alludes to ample concentration of permanganate. Maximum power density using $0.2 \mathrm{~g} / \mathrm{L}$ of permanganate is $0.95 \mathrm{~W} / \mathrm{m}^{2}$, while it equals $0.03 \mathrm{~W} / \mathrm{m}^{2}$ for aerated cathode MFC. Also, relevant internal resistance equals $500 \Omega$ that is less than that in aerated cathode $\operatorname{MFC}(1300 \Omega)$.

Figure 9 shows effects of variation of permanganate concentration on the current density for different values of external resistance. With regard to this figure, it can be seen that effect of permanganate concentration is more for lower values of external

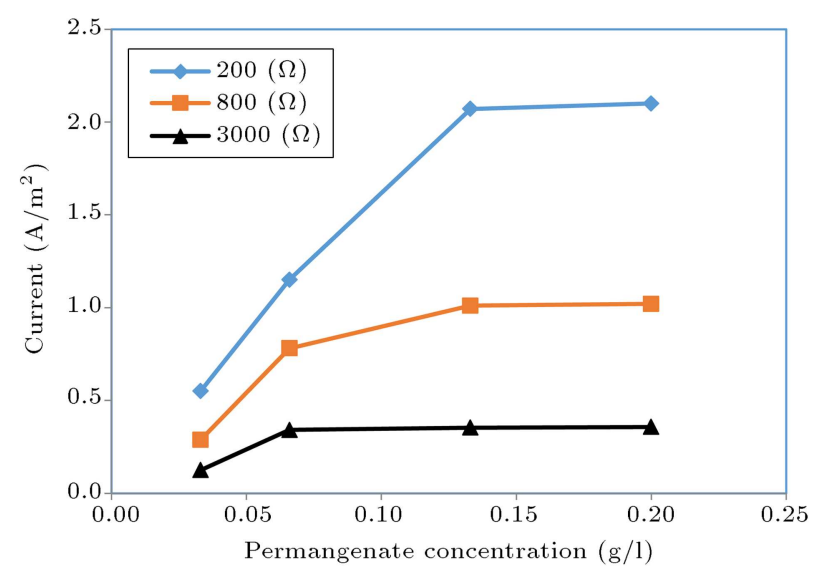

Figure 9. Effects of variations of permanganate concentration on the current density for different values of external resistance $(200,800$, and $3000 \Omega$ ). 
resistance. Thus, to product much current from cell and better wastewater treatment, it is essential to use MFC with low external resistance.

\subsection{Modelling of polarization curves}

The maximum electromotive force generated from an MFC can be predicted thermodynamically by the Nernst equation:

$$
E_{\mathrm{emf}}=E^{0}-\frac{R T}{n F} \ln (\Pi)
$$

where $E^{0}$ is the standard cell electromotive force, $R=$ $8.314 \mathrm{~J} / \mathrm{mol} . \mathrm{K}$ the gas constant, $T$ the temperature $(\mathrm{K}), n$ the number of transferred electrons (dimensionless), $F$ the Faraday's constant $(96485 \mathrm{c} / \mathrm{mol})$, and $\Pi$ the ratio of activities of the products divided by reactants raised to their respective stoichiometric coefficients [28].

In practice, due to irreversible losses, the actual output voltage is less than the one resulted from the ideal equation. The significant losses that affect MFC operation are activation loss, ohmic loss, and mass transfer loss that take place in both the anode and cathode. The operational voltage output as a function of current density can be calculated as follows [30]:

$$
\begin{aligned}
V= & \mathrm{OCV}-\eta_{\text {act }}-\eta_{\text {ohmic }}-\eta_{\text {conc }} \\
V= & \mathrm{OCV}-\left(a_{\text {act }}+b_{\text {act }} \times \ln (i)\right)-\left(i \times S \times R_{\text {ohmic }}\right) \\
& -C \times \ln \left(\frac{i_{L}}{i_{L}-i}\right)
\end{aligned}
$$

$\eta_{\text {act }}$ is activation loss due to activation energy reactions and is limited in rapid voltage drop as current flows the circuit (at high external resistance); $\eta_{\text {ohmic }}$ is ohmic loss that is consequence of ionic and electronic resistance, is proportional to the ohmic resistance of the system and current density, and corresponds to the linear region of polarization curve (middle current). Ohmic loss is a function of electrolyte conductivity and membrane permeability; $\eta_{\text {conc }}$ is concentration or mass transfer loss that decreases when flux of reactants to electrod increases and accumulation of products decreases and it is most apparent in high current density (low external resistance); Open Circuit Voltage (OCV) is determined

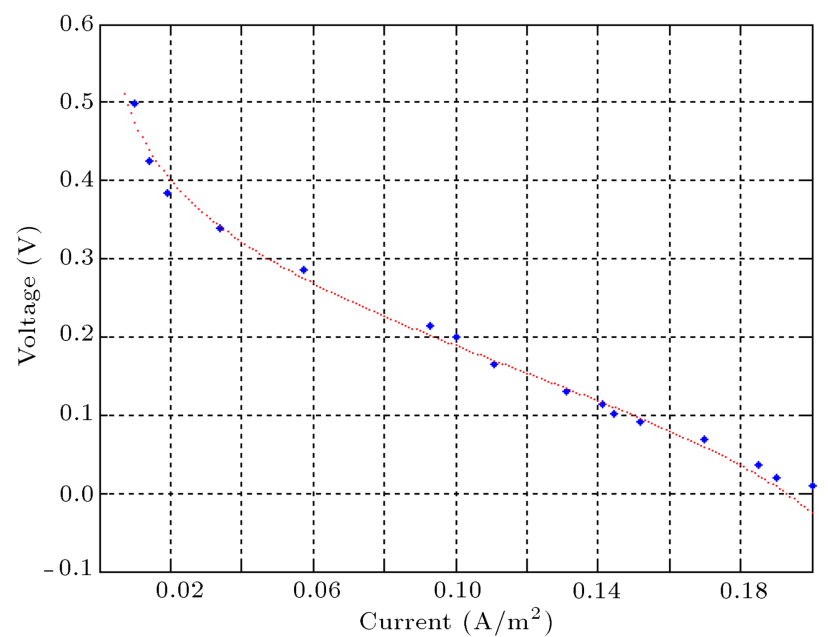

Figure 10. Fitting of nonlinear model (Eq. (6)) on empirical polarization data for oxygen as cathodic electron acceptor at $24^{\circ} \mathrm{C}, r=0.999$.

empirically at infinite external resistance; and $S$ is the cross sectional area of cathode.

Eq. (6) can be used to fit a nonlinear model on experimental polarization curve by nonlinear newton raphson method. Then, values of parameters $\left(a_{\text {act }}\right.$, $b_{\text {act }}, C$, and $i_{L}$ ) and regression coefficient $(r)$ are calculated. For example, the result of fitting Eq. (6) on empirical polarization curve of air cathode at $24^{\circ} \mathrm{C}$ is shown in Figure 10.

The values of parameters in Eq. (6) for oxygen and permanganate as oxidants at $33^{\circ} \mathrm{C}$ and $24^{\circ} \mathrm{C}$ are presented in Table 1 . Using these parameters, values of different losses are separately predictable. Figure 11 shows variations of different losses as functions of current density using oxygen $\left(33^{\circ} \mathrm{C}, 24^{\circ} \mathrm{C}\right)$ and permanganate $\left(0.2 \mathrm{~g} / \mathrm{L}, 33^{\circ} \mathrm{C}\right)$ in the cathode of MFC.

As can be seen in Figure 11, the values of losses increase with current density. Also, effects of activation loss and concentration loss (mass transfer loss) are apparent in low and high values of current density, respectively. Figure 11(a) shows that activation loss has more contribution than other losses. This is due to reduction of oxygen without utilization of ptcatalyst in cathode chamber. As shown in Figure 11(a) and (b), with decreasing the temperature from $33^{\circ} \mathrm{C}$ to $24^{\circ} \mathrm{C}$, activation and concentration losses become more

Table 1. Values of different parameters in Eq. (6) for oxygen and permanganate as oxidants at $33^{\circ} \mathrm{C}$ and $24^{\circ} \mathrm{C}$.

\begin{tabular}{cccccccc}
\hline Oxidant & Temperature & $\boldsymbol{C}$ & $\boldsymbol{i}_{\boldsymbol{L}}$ & $\boldsymbol{R}_{\text {ohmic }}$ & $\boldsymbol{a}_{\text {act }}$ & $\boldsymbol{b}_{\text {act }}$ & $\boldsymbol{r}$ \\
\hline Oxygen & $33^{\circ} \mathrm{C}$ & $0.003-0.0002 i$ & $0.202-0.015 i$ & $557.57-46 i$ & $0.365-0.009 i$ & $0.086-0.002 i$ & 0.9997 \\
Oxygen & $24^{\circ} \mathrm{C}$ & $0.076-0.0001 i$ & 0.22 & $210.38-0.01 i$ & 0.46 & 0.097 & 0.9992 \\
$\begin{array}{c}\text { Permanganate } \\
(0.033 \mathrm{~g} / \mathrm{L})\end{array}$ & $33^{\circ} \mathrm{C}$ & $0.0122-0.011 i$ & $0.615-0.011 i$ & $71.26-91 i$ & $0.333-0.033 i$ & $0.141-0.011 i$ & 0.9996 \\
$\begin{array}{c}\text { Permanganate } \\
(0.2 \mathrm{~g} / \mathrm{L})\end{array}$ & $24^{\circ} \mathrm{C}$ & $0.083-0.053 i$ & $2.43-0.13 i$ & $240.03-60 i$ & $0.013-0.047 i$ & $0.056-0.026 i$ & 0.9991 \\
\hline
\end{tabular}




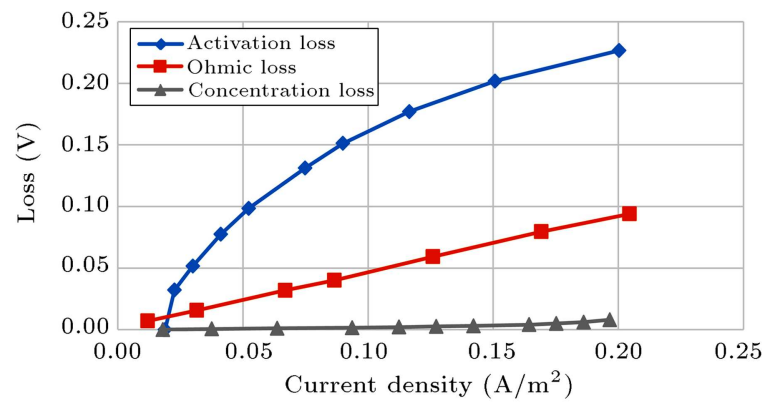

(a)

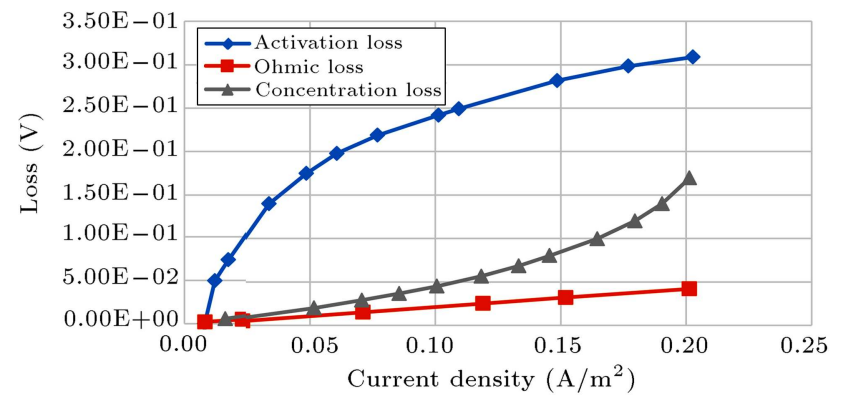

(b)

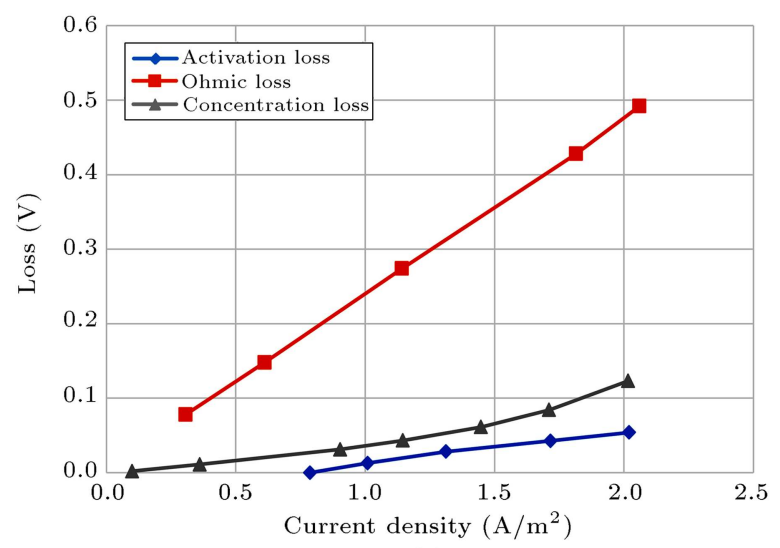

(c)

Figure 11. Variations of different losses as functions of current density using (a) oxygen $\left(33^{\circ} \mathrm{C}\right),(\mathrm{b})$ oxygen $\left(24^{\circ} \mathrm{C}\right)$, and $(\mathrm{c})$ permanganate $\left(0.2 \mathrm{~g} / \mathrm{L}, 33^{\circ} \mathrm{C}\right)$ in the cathode of $\mathrm{MFC}$.

effective, which is the consequence of abatement of electrochemical reaction rate and mass transfer coefficient in the anode and cathode chambers. With regard to Figure 11(a) and (c), contribution of activation loss for oxygen as oxidant is more than permanganate. This is due to high redox potential of permanganate in comparison to oxygen.

\section{Conclusions}

In this paper, we investigated treatment of petroleum wastewater of Isfahan Refinery (COD $=213.9 \mathrm{mg} / \mathrm{L}$, $\mathrm{pH}=7)$ in a two-chamber microbial fuel cell having $350 \mathrm{~mL}$ of anode and cathode capacity. Oxygen and potassium permanganate were used as cathodic electron acceptors. Also, the effects of variations of temperature and external resistance on the treatment of PRW were investigated. The most important conclusions of this paper are as follows:

- High current is generated using permanganate and much substrate degrades due to both its higher recovery potential and its independency of catalyst in comparison to oxygen;

- Reduction in the output power with decreasing temperature is due to reduction in activity of the microorganism and cathode reducing potential;

- To increase the values of columbic efficiency and wastewater treatment, it is essential to use MFC with low external resistance;

- Optimized concentration of permanganate to generate power equals $0.2 \mathrm{~g} / \mathrm{L}$ and its relevant internal resistance equals $500 \Omega$ that is lower than that of aerated cathode MFC (1300 $\Omega)$;

- By using permanganate as electron acceptor, maximum power density was $0.95 \mathrm{~W} / \mathrm{m}^{2}$ and COD removal efficiency reached $78 \%$;

- Two-chamber MFC with low columbic efficiency was used in this paper. To increase the values of $C_{E}$ and PRW treatment, microbial fuel cells in optimized structures, like one-chamber MFC, can be used.

\section{References}

1. Ocoelh, A., Castro, A., Dezotti, M. and Anna, GL. "Treatment of petroleum refinery wastewater by advanced oxidation processes", J. Hazard. Mater., 137(1), pp. 178-184 (2006).

2. Farhadiah, M., Vachelad, C., Duchez, D. and Larroche, C. "In situ bioremediation of monoaromatic pollutant in ground water", J. Bio. Technol., 99(13), pp. 52965308 (2008).

3. Ishak, S., Malakahmad, A. and Isa, M.H. "Refinery waste water biological treatment: A short review", $J$. Sci. Indus. Res., 71, pp. 251-256 (2008).

4. Jou, C.J.G. and Huang, G.C. "A pilot study for oil refinery wastewater treatment using a fixed film bioreactor", Adv. Env. Res., 7(2), pp. 463-469 (2003).

5. Ahmed, G.H., Kutty, S.R.M. and Isa, M.H. "Petroleum refinery effluent biodegradation in sequencing batch reactor", Int. J. App. Sci. Technol, 1(6), pp. 179-183 (2011).

6. Kutty, S.R.M., Gasim, H.A., Khamaruddin, P.F. and Malakahmad, A. "Biological treatability study for refinery wastewater using bench scale sequencing batch reactor systems", Water Resources Management, 145, pp. 691-699 (2011).

7. Ma, F., Guo, J.B., Zhao, L.J., Chang, C.C. and Cui, D. "Application of bioaugmentation to improve the activated sludge system into the contact oxidation 
system treating petrochemical wastewater", Biores. Technol., 100(2), pp. 597-602 (2009).

8. Shahrezaei, F., Mansouri, Y., Zinatizadeh, A.A.L. and Akhbari, A. "Process modeling and kinetic evaluation of petroleum refinery wastewater treatment in a photocatalytic reactor using $\mathrm{TiO}_{2}$ nanoparticles", Powder Technol., 221, pp. 203-212 (2012).

9. Priambodo, R., Shih, Y.J., Huang, Y.J. and Huang, Y.H. "Treatment of real wastewater using semi batch (photo)-electro-Fenton method", Sustain. Env. Res., 21, pp. 389-393 (2011).

10. Logan, B.E., Microbial Fuel Cells, John Wiley \& Sons Inc., Hoboken, NJ. (2008).

11. Ahn, Y. and Logan, B.E. "Effectiveness of domestic wastewater treatment using microbial fuel cells at ambient and mesophilic temperatures", Biores. Technol., 101(2), pp. 469-475 (2010).

12. Mohan, S.V., Mohanakrishna, G., Velvizhi, G., Babu, V.L. and Sarma, P.N. "Bio- catalyzed electrochemical treatment of real field dairy wastewater with simultaneous power generation", Biochem. Eng. J., 51(1), pp. 31-39 (2010).

13. Mohanakrishna, G., Mohan, S.V. and Sarma, P.N. "Bio-electrochemical treatment of distillery wastewater in microbial fuel cell facilitating decolorization and desalination along with power generation", $J$. Hazardous Materials, 177(1), pp. 487-494 (2010).

14. Pant, D., Van Bogaert, G., Diels, L. and Vanbroekhoven, K.A. "review of the substrates used in microbial fuel cells (MFCs) for sustainable energy production", Bio. Technol., 101(6), pp. 1533-1543 (2010).

15. Morris, J.M. and Jin, S. "Feasibility of using microbial fuel cell technology for bioremediation of hydrocarbons in groundwater", J. Env. Sci. Heal., 43(1), pp. 18-23 (2007).

16. Morris, J.M., Jin, S., Crimi, B. and Pruden, A. "Microbial fuel cell in enhancing anaerobic biodegradation of diesel", Chem. Eng. J., 146(2), pp. 161-167 (2009).

17. Mohan, S.V. and Chandrasekhar, K. "Self-induced bio-potential and graphite electron accepting conditions enhances petroleum sludge degradation in bioelectrochemical system with simultaneous power generation", Biores. Technol., 102(20), pp. 9532-9541 (2011).

18. Luoa, H., Liua, G., Zhanga, R. and Jinb, S. "Phenol degradation in microbial fuel cells", Chem. Eng. J., 147, pp. 259-264 (2009).

19. Mohan, S.V., Veer Raghavulu, S., Peri, D. and Sarma, P.N. "Integrated function of microbial fuel cell (MFC) as bio-electrochemical treatment system associated with bioelectricity generation under higher substrate load", Biosen. Bioelec., 24, pp. 2021-2027 (2009).

20. Antonopoulou, G., Stamatelatou, K., Bebelis, S. and Lyberatos, G. "Electricity generation from synthetic substrates and cheese whey using a two chamber microbial fuel cell", Biochem. Eng. J., 50(1), pp. 10-15 (2010).

21. Jiang, D., Li, B., Jia, W. and Lei, Y. "Effect of inoculum types on bacterial adhesion and power production in microbial fuel cells", App. Biochem. Biotechnol., 160(1), pp. 182-196 (2010).

22. Zhang, L., Zhu, X., Li, J., Liao, Q. and Ye, D. "Biofilm formation and electricity generation of a microbial fuel cell started up under different external resistances", Journal of Power Sources, 196(15), pp. 6029-6035 (2011).

23. APHA, AWWA, WPCF, Standard Methods for Examination of Water and Wastewater, 20th Ed., American Public Health Association, Washington, DC (1998).

24. Min, B., Kim, J., Oh, S., Regan, J.M. and Logan, B.E. "Electricity generation from swine wastewater using microbial fuel cells", Water Research, 39(20), pp. 4961-4968 (2005).

25. Mardanpour, M.M., Esfahany, M.N., Behzad, T. and Sedaqatvand, R. "Single chamber microbial fuel cell with spiral anode for dairy wastewater treatment", Biosensors and Bioelectronics, 38(1), pp. 264-269 (2012).

26. Larrosa-Guerrero, A., Scott, K., Head, I.M., Mateo, F., Ginesta, A. and Godinez, C. "Effect of temperature on the performance of microbial fuel cells", Fuel, 89(12), pp. 3985-3994 (2010).

27. Mohan, S.V., Mohanakrishna, G., Velvizhi, G., Babu, V.L. and Sarma, P.N. "Bio-catalyzed electrochemical treatment of real field dairy wastewater with simultaneous power generation", Biochem. Eng. J., 51(1), pp. 32-39 (2010).

28. Rismani-Yazdi, H., Carver, S.M., Christy, A.D. and Tuovinen, O.H. "Cathodic limitations in microbial fuel cells: An overview", J. Power Sources, 180(2), pp. 683-694 (2008).

29. You, S., Zhao, Q., Zhang, J., Jiang, J. and Zhao, S. "A microbial fuel cell using permanganate as the cathodic electron acceptor", J. Power Sources, 162(2), pp. 1409-1415 (2006).

30. Wen, Q., Wu, Y., Cao, D., Zhao, L. and Sun, Q. "Electricity generation and modeling of microbial fuel cell from continuous beer brewery wastewater", Bioresource Technology, 100(18), pp. 4171-4175 (2009).

\section{Biographies}

Mehdi Bagheri-Esfe received his BSc degree in Petrochemical Engineering from the Islamic Azad University, Shahreza Branch (2009), and his MS degree in Chemical Engineering from Isfahan University of Technology (2013). His research interest includes wastewater treatment in microbial fuel cells (MFCs).

Hamed Bagheri-Esfe is currently an Assistant Pro- 
fessor in Mechanical Engineering Group at Shahreza University, Shahreza, Iran. He completed his BSc degree in Mechanical Engineering (Thermal-Fluid) at Kashan University, his MS degree in Mechanical Engineering at Birjand University (1st in rank), and his
PhD degree at Amirkabir University of Technology. For his PhD program, he worked on effects of nonequilibrium condensation in steam turbines. His fields of interest include computational fluid dynamics, compressible flows, and two-phase flows. 